This PDF is a selection from a published volume from the National Bureau of Economic Research

Volume Title: Labor Markets and Firm Benefit Policies in Japan and the United States

Volume Author/Editor: Seiritsu Ogura, Toshiaki Tachibanaki and David A. Wise, editors

Volume Publisher: University of Chicago Press

Volume ISBN: 0-226-62094-8

Volume URL: http://www.nber.org/books/ogura03-1

Conference Date: January 20-23, 2000

Publication Date: January 2003

Title: The Role of Firms in Welfare Provision

Author: Toshiaki Tachibanaki

URL: http://www.nber.org/chapters/c10311 


\title{
The Role of Firms in Welfare Provision
}

\author{
Toshiaki Tachibanaki
}

\subsection{Introduction}

Firms support welfare provision in various ways. First, firms help finance social security benefits by contributing to social insurance programs, such as public pensions, unemployment compensation, and medical care. Second, firms organize and manage their own systems of welfare provision for their employees. Typical examples are enterprise pensions (or occupational pensions) and health insurance systems. Third, firms provide their employees with housing services and other nonstatutory welfare services directly. The third form is typically observed in large Japanese firms.

The distinction between direct and indirect methods of welfare provision is particularly important. An indirect method implies that firms contribute to both employees and citizens who are anonymous from the firm's point of view. An example is a social insurance system, where firms are unable to identify who the actual beneficiaries are. Firms simply contribute to a social insurance fund. Of course, employees also contribute to social insurance systems. A direct method implies that firms contribute directly and exclusively to their own employees. Thus, firms can identify the actual beneficiaries of the welfare provision because they support only their employees. Typical examples are enterprise pensions, health insurance systems, and housing services. An interesting question is whether such direct and indirect methods have different effects on workers' behavior, welfare systems' management, or firms' economic performance.

In principle, there are three groups that finance welfare provision. They are (a) fellow citizens, like employees and the self-employed; (b) firms; and

Toshiaki Tachibanaki is professor of economics at the Faculty of Economics, Kyoto University. 
(c) the public sector (i.e., general tax revenues). Fellow citizens and firms can contribute in various ways, as indicated previously for firms. The public sector can also contribute in various ways. Some countries, like Denmark, rely largely on general tax revenues to provide welfare services, whereas other countries, like Japan and the United States, do not rely heavily on general tax revenues. Why are there differences across countries?

\subsection{International Comparisons}

It is useful to review current international methods for providing social and welfare services, and in particular how welfare services are provided by the public sector. In other words, what is the magnitude of welfare provision, and the distribution of taxes or social security contributions to support it, in each country? Tables 11.1 and 11.2 present social expenditures and tax revenue and social security contribution rates, respectively, for several advanced countries. I focus largely on Japan and the United States. The statistics in these tables are shown as percentage shares of gross domestic product (GDP).

The tables highlight a remarkable fact: Japan and the United States have the lowest shares of social expenditure and the lowest burden of taxes and social security contributions among the advanced countries, suggesting that the public sector does not provide a large amount of welfare services. The rates of social expenditure in Japan and the United States in 1993 were

Table 11.1 Social Expenditures (\% GDP)

\begin{tabular}{llllll}
\hline & 1980 & 1985 & 1990 & 1993 & 1994 \\
\hline Austria & 22.3 & 24.0 & 23.6 & 25.6 & n.a. \\
Belgium & 25.4 & 28.2 & 26.4 & 27.2 & n.a. \\
Denmark & 27.6 & 26.5 & 28.2 & 31.0 & n.a. \\
Finland & 18.9 & 23.5 & 25.3 & 34.8 & 34.1 \\
France & 23.5 & 27.0 & 26.0 & 28.7 & n.a. \\
Germany & 25.8 & 26.5 & 24.8 & 29.8 & n.a. \\
Greece & 10.8 & 16.2 & 17.1 & 16.9 & n.a. \\
Ireland & 19.7 & 23.3 & 19.3 & 21.3 & 20.7 \\
Italy & 18.4 & 21.7 & 23.1 & 25.0 & n.a. \\
Luxembourg & 24.8 & 24.6 & 23.9 & 25.3 & n.a. \\
The Netherlands & 28.5 & 28.9 & 29.2 & 30.5 & n.a. \\
Portugal & 11.6 & 11.9 & 14.4 & 17.5 & n.a. \\
Spain & 16.5 & 18.7 & 19.8 & 22.5 & n.a. \\
Sweden & 28.9 & 30.4 & 31.6 & 37.5 & n.a. \\
United Kingdom & 18.7 & 21.5 & 20.2 & 24.0 & n.a. \\
United States & 12.7 & 12.9 & 13.8 & 15.3 & n.a. \\
Japan & 10.2 & 11.3 & 11.2 & 12.5 & 13.0 \\
\hline
\end{tabular}

Source: OECD (1998).

Note: n.a. $=$ not available 


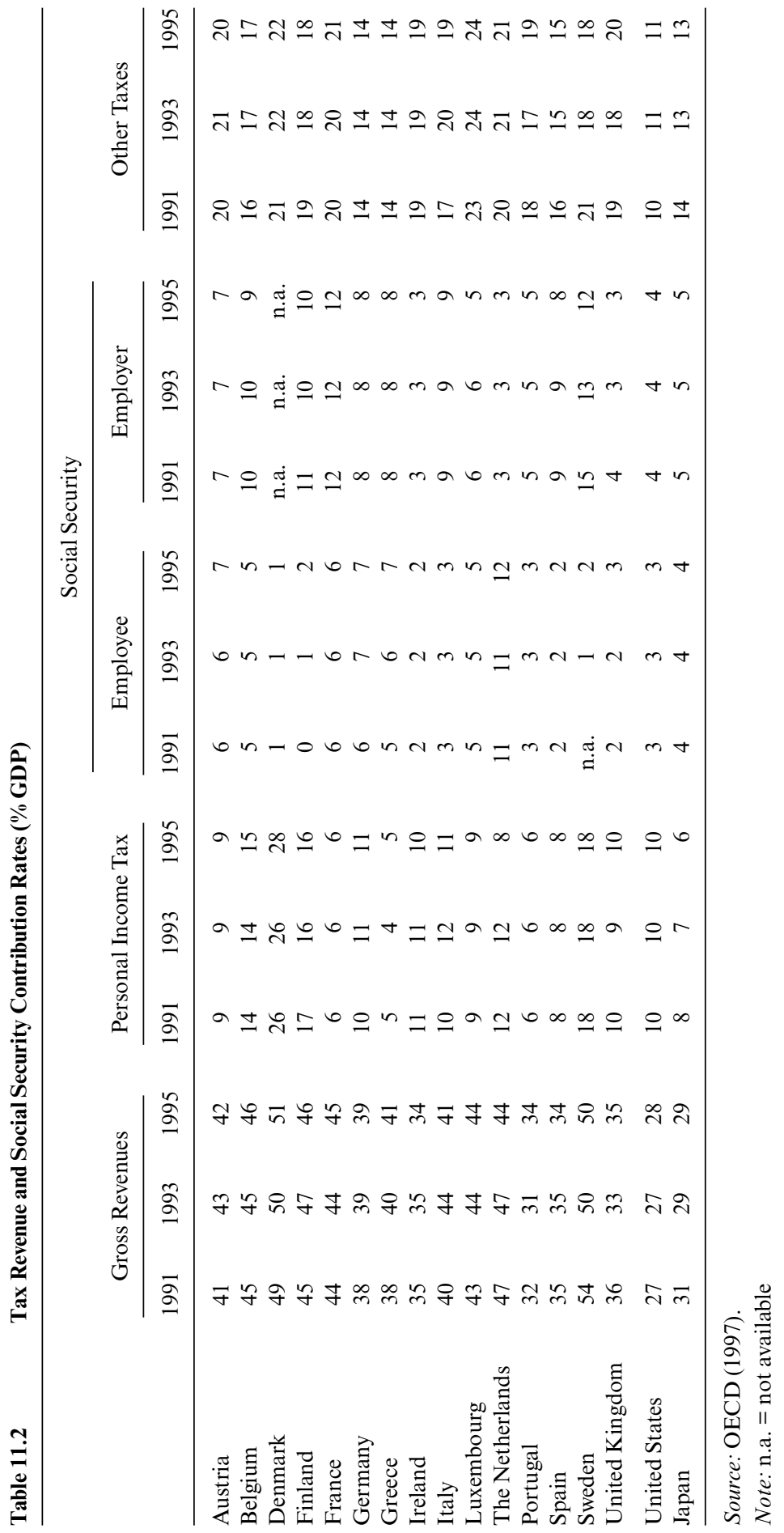


12.5 percent and 15.3 percent, respectively, much lower than the rate of the average European country. The rates of government revenue for both countries were below 30 percent in 1993, again much lower than the average rate among European countries. The public sector in Japan and the United States does not play an important role in welfare provision.

Very high shares of social expenditure, tax revenues, and social security contributions are observed in Scandinavian countries like Denmark, Finland, and Sweden, which are known as welfare states. The public sector plays a very important welfare provision role in these countries. Tables 11.1 and 11.2 suggest that both Japan and the United States are representative examples of nonwelfare states.

Tachibanaki (2000b) provides an extensive discussion of the reasons why Japan is a nonwelfare state. The paper emphasizes the roles of both family and firms in welfare provision, which diminish the role of the public sector. Rein (1996) stresses that focusing only on the state leads to an underestimate of the level of social protection in society, suggesting that the United States is not the exceptional case of a welfare laggard. Welfare is provided not only by the public sector in the United States, but also by individuals and enterprises, as represented by health insurance programs and enterprise pension systems.

Scandinavian countries are the other extreme because they are welfare states, with welfare levels much higher than that of the United States. Also, the income distribution is much more equal in Scandinavia, for the following two reasons: First, pretransfer income is more equally distributed. Second, a stronger redistributive policy through tax and social security systems is in place. Freeman, Topel, and Swedenborg (1997) have published an interesting book about the difference between the American and Swedish views on the welfare state.

What is the role of firms in welfare provision? Figure 11.1 presents a time series of the contributions of firms to social security. Figure 11.2 presents the shares of social security funding, including those of beneficiaries' contributions and tax revenues, for several countries. These figures were published by Katsumata and Morita (1999) and Katsumata (2000).

They show several interesting results regarding the role of firms in welfare provision. First, both Sweden and France have very high rates of contributions by firms. About two-thirds of total social security costs are borne by firms in Sweden, and about half in France. It is interesting to note that Denmark, which is one of the welfare states, is quite different from Sweden. The role of the firm is very minor in Denmark: Seventy percent of social security financing comes from general tax revenues. Thus, there are differences even within Scandinavia regarding the financial sources of welfare provision.

Second, the firm contribution shares for Germany, Japan, the United Kingdom, and the United States look similar, ranging from 20 to 30 per- 


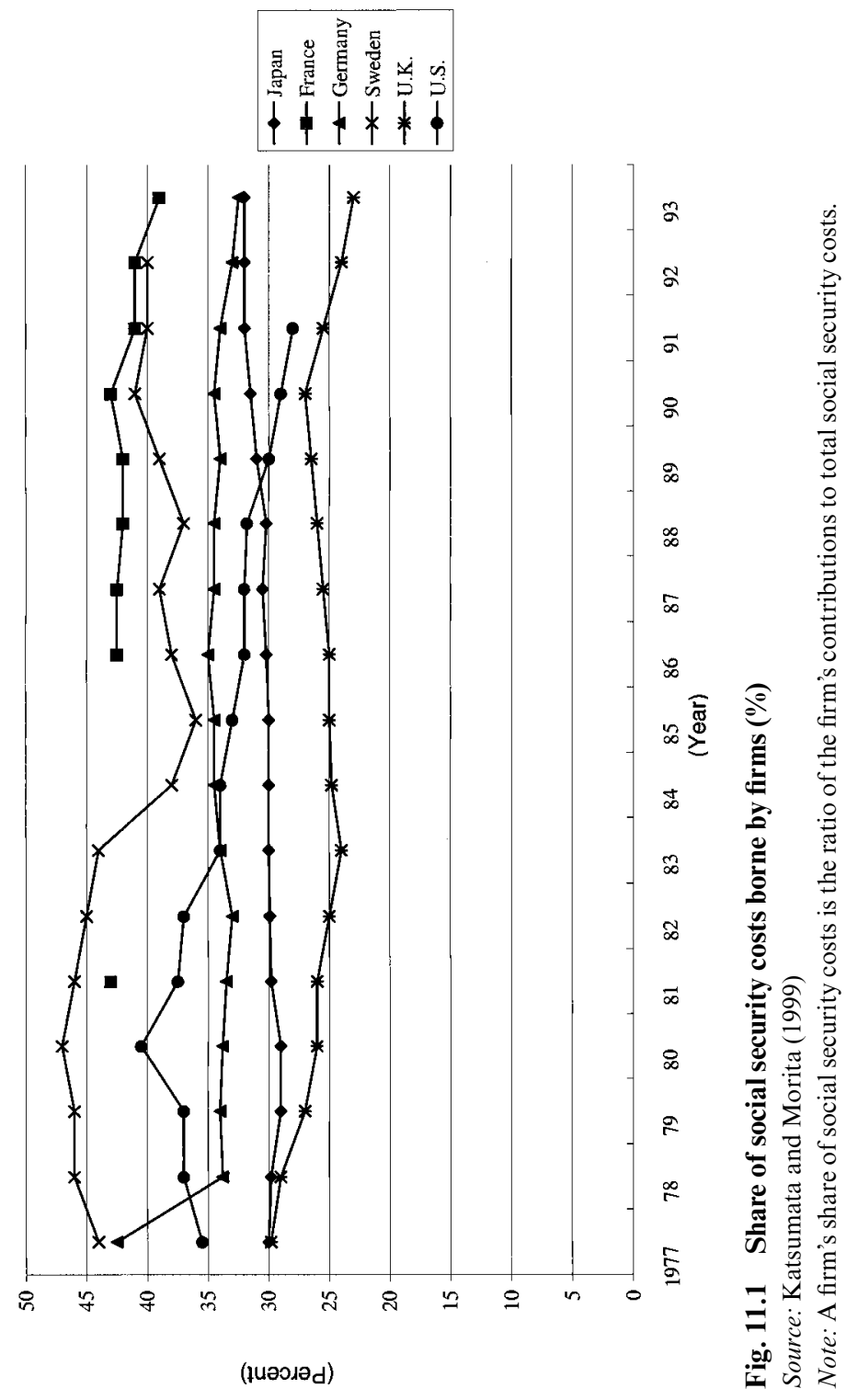




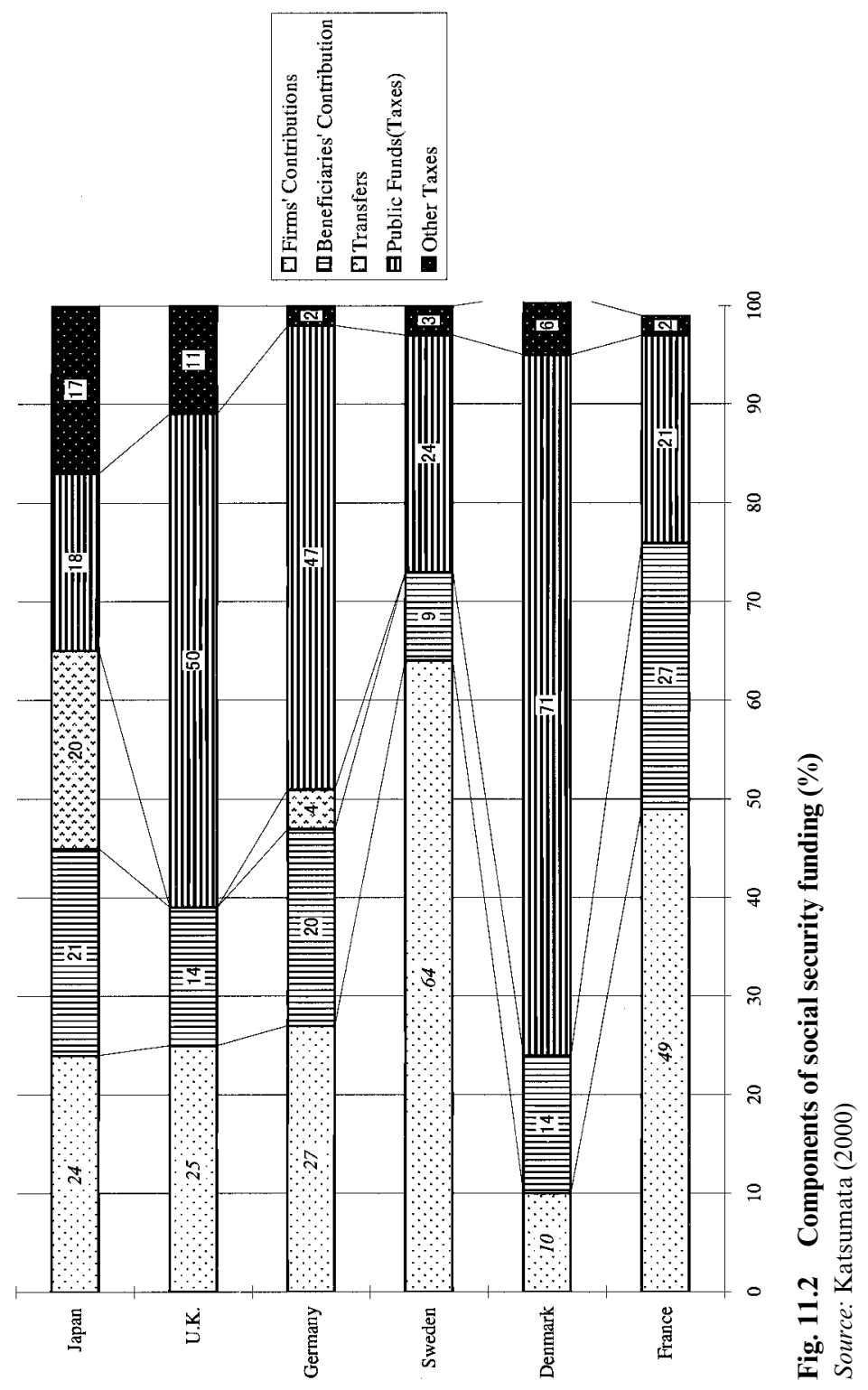


cent. The contributions of firms to welfare provision are modest in these countries. If we rank these countries according to the role of firms, Germany ranks highest, followed by the United Kingdom, Japan, and the United States. It is again striking that both Japan and the United States are at the bottom for this measure.

Despite the fact that firm contributions to welfare provision play a minor role in both Japan and the United States, there are differences between the two countries. Japanese firms, in particular larger firms, make fairly significant contributions in the form of nonstatutory fringe benefits. American firms contribute to enterprise pensions and health insurance systems that are not managed by the public sector. The Japanese nonstatutory fringe benefit system will be discussed below.

Third, it is necessary to understand why several European countries like France, Germany, and Sweden have high rates of firm contributions to social security. For Germany, it is widely known that the Bismarckian social insurance system encouraged firms to contribute to social security along with workers in order to enhance worker productivity. This is sometimes called a carrot-and-stick policy, and it led the Prussian society and economy into the Industrial Revolution. It is the origin of a social policy that was popular both before and after World War II. It is ironic that German social policy was applauded by the Marxist school of economics in this period in Japan. It has, to a certain extent, dominated Japan's labor and social security policy during the postwar period. It is not an exaggeration to say that welfare policy in Japan followed the tradition of social policy in Germany and that this is still reflected in the current system, although there have been modifications.

For France, there are two possible explanations. First, there is a tradition of social insurance systems that are delineated by occupation, firm, or both. Each occupational group or firm has its own separate social insurance system. In such a case, firms are normally willing to contribute more to employees because they can expect high employee motivation in return. Second, the French trade union movement has been fairly strong, and thus it has had a strong voice to use against employers during the postwar period. It is not surprising that firms have to accept a high share of social insurance costs under such circumstances. It is, nevertheless, necessary to take into consideration the incidence of firms' contributions to social insurance in France in order to draw a clear conclusion concerning the above two forces.

For Sweden, a story similar to that of France can be applied to explain the high contributions of firms. Trade unions, in particular blue-collar unions, have been fairly powerful. Additionally, the welfare state has received wide support. Thus, all economic agents, including firms, have been willing to contribute to welfare provision. 


\subsection{Japan}

Having examined international statistics, my next task is to evaluate the contribution of firms to welfare provision in Japan. There are basically four important components of firms' contributions to welfare. The first is statutory contributions to social security, which account for about 50 percent of nonwage labor payments. The second is nonstatutory fringe benefits. The third is retirement allowances (or severance payments). The residual fourth is the sum of payments toward real goods, expenditures on education and training for employees, hiring costs, and so forth.

Table 11.3 shows the share of each component as a fraction of total labor costs. The largest share is that of statutory contributions to social security, about 8 to 10 percent. The second largest share is accounted for by severance payments, and the third is due to nonstatutory fringe benefits. Table 11.3 reveals significant differences in nonwage payments by firm size. This is particularly true in the case of retirement allowances (severance payments) and nonstatutory fringe benefits, whereas there is no difference in statutory contributions to social security. The differences in severance payments and nonstatutory fringe benefits can be explained by the "ability to pay" hypothesis: Larger firms are able to offer higher severance payments and nonstatutory fringe benefits than smaller firms, due to their extra revenues. This is probably the most salient feature about firms' contributions to welfare provision in Japan.

How large are the differences by firm size? Table 11.4 gives the answer. First, the largest difference is for housing payments. Larger firms have their own housing facilities for married households and dormitories for singles. Employees can live in these facilities and pay very low rents because they are heavily subsidized by the firms. The higher payments for housing by larger firms reflect the amounts of the subsidies and the purchase costs of these houses and dormitories. Overall, expenditures on housing account for over 46 percent of nonstatutory fringe benefits. This is by far the highest share of any component of these benefits. However, this share varies substantially by firm size. Firms with over 5,000 employees pay an average of 23,600 yen per month, per employee, whereas firms with thirty to ninety-nine employees pay only 6,900 yen per month per employee. Therefore, the payments per employee by large firms are about 3.4 times those by small firms. Payments are probably near zero for the smallest firms, but there are no data with which to confirm this conjecture.

Second, table 11.4 suggests that firms in Japan pay amazingly varied types of fringe benefits, including payments for cultural and athletic facilities, congratulations and condolences, food, and so on. These payments are sometimes called East Asian types of fringe benefits.

The results in tables 11.3 and 11.4 document extraordinary differences in welfare provision by firm size. This is particularly true for severance pay- 


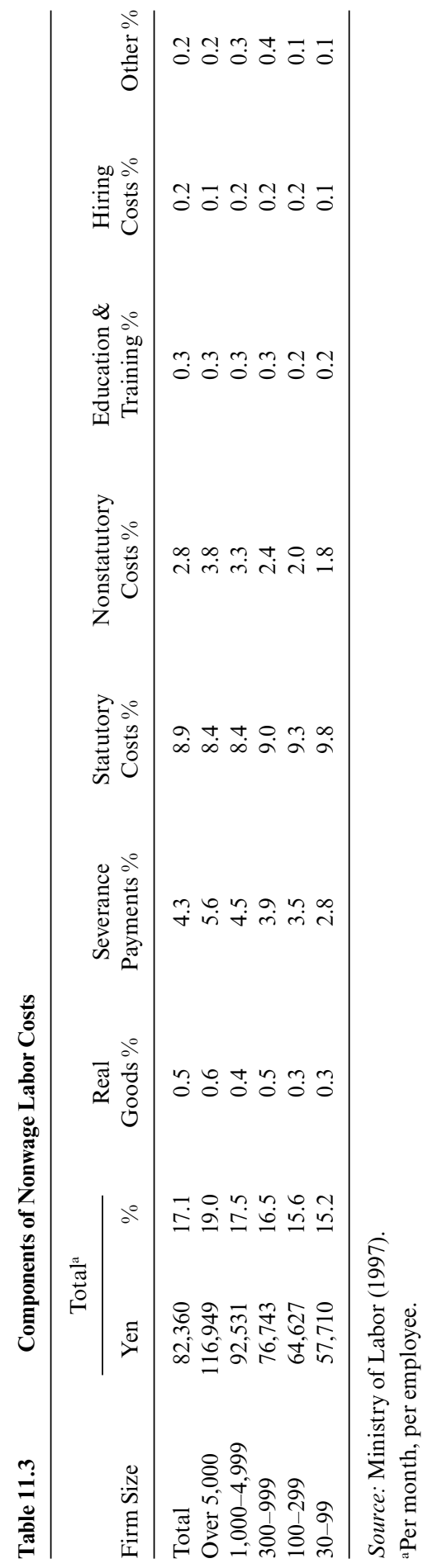


Components of Nonstatutory Fringe Benefits (\%)

\begin{tabular}{lrrrrrr}
\hline & \multicolumn{7}{c}{ Firm Size } \\
\cline { 2 - 7 } & Total & $5,000+$ & $1,000-4,999$ & $300-999$ & $100-299$ & $30-99$ \\
\hline Total & 100.0 & 100.0 & 100.0 & 100.0 & 100.0 & 100.0 \\
Housing & 46.3 & 49.6 & 54.1 & 51.8 & 33.8 & 19.4 \\
Medical insurance & 5.6 & 7.9 & 4.7 & 3.5 & 4.7 & 3.3 \\
Food & 10.6 & 9.8 & 9.4 & 10.4 & 12.7 & 14.8 \\
Culture and athletics & 8.6 & 8.1 & 7.1 & 7.8 & 9.9 & 14.1 \\
Private insurance & 8.4 & 3.2 & 6.8 & 9.3 & 14.6 & 22.5 \\
Additional casualty & & & & & & \\
$\quad$ payments & 1.7 & 0.4 & 0.6 & 2.1 & 3.9 & 5.8 \\
Congratulations and & & & & & & \\
$\quad$ condolences & 3.4 & 2.7 & 3.7 & 3.2 & 4.0 & 4.8 \\
Aid to savings & 3.9 & 6.0 & 3.3 & 3.1 & 2.4 & 1.3 \\
Other & 11.6 & 12.3 & 10.3 & 8.7 & 13.9 & 13.9 \\
Amount per month & & & & & & \\
$\quad$ per employee (yen) & 13,682 & 23,601 & 17,439 & 11,317 & 8,069 & 6,907 \\
\hline
\end{tabular}

Source: Ministry of Labor (1997).

Table 11.5 Components of Statutory Social Insurance Contributions by Firms

\begin{tabular}{lc}
\hline & Percentage of Contribution \\
\hline Health insurance & 32.1 \\
Public pension & 52.7 \\
Labor insurance & 14.2 \\
Unemployment & 7.0 \\
Labor casualty & 7.2 \\
Child allowance & 0.7 \\
Other & 0.4 \\
Total & 100.0 \\
\hline
\end{tabular}

Source: Ministry of Labor (1997).

ments and nonstatutory fringe benefits. Tachibanaki (1996), Tachibanaki and Taki (2000), and Tachibanaki and Noda (2000) discuss the dual structure of the Japanese labor market, which implies a significant difference in wages, productivity, employment stability, union behavior, and the like by firm size. Severance payments and nonstatutory fringe benefits are no exceptions to this dual structure.

Table 11.5 shows how firms' statutory contributions to social security are distributed. The highest share, nearly 53 percent, is paid to public pension programs. An additional 32 percent is contributed to health insurance, and 14 percent goes to unemployment insurance and labor casualty insurance. Historically, the role of unemployment compensation has been minor, due to the low rate of unemployment. This is no longer true in light 
of the fact that the unemployment rate reached over 5 percent in 2003 . Nevertheless, public pensions and health insurance account for the vast majority of firms' contributions to social security.

\subsection{Theory}

This section presents economic theories to explain the considerably high share of nonwage payments, particularly nonstatutory fringe benefits.

It is crucial to understand that a large part of fringe benefits, such as payments to private retirement systems (including severance payments), life insurance systems, health benefits, and other agreed-upon plans, are $d e-$ ferred compensation. The intrinsic nature of deferred compensation is the main reason for both employers' and employees' preferences for fringe benefits, although factors that are not associated with deferred payments must also be examined.

Rice (1966) gives four factors for explaining the growth of fringe benefits in the United States: (a) preferential treatment under federal personal income tax laws; (b) savings that are made possible by group purchase of some benefits, notably insurance; (c) efforts to reduce turnover in the face of rising costs of labor turnover; and (d) unionization. Woodbury (1983) adds three factors: (e) preferential treatment under federal corporate income taxes, since contributions by employers to pension funds and insurance benefits are largely deductible from employers' taxable income; (f) the changing age composition of the labor force; and (g) the effect of rising income. Hart (1984) provides a useful survey of these results for the 1960s to early 1980s and analyzes nonwage labor costs.

These factors have been scrutinized recently in an attempt to interpret the rationales behind the payment of fringe benefits, and new factors have been added. I summarize them under the following five headings: (a) agency theory; (b) tax advantage theory; (c) worker preference; (d) cost savings apart from tax advantages; and (e) better industrial relations. These are mainly factors explaining the level of fringe benefits. However, by reinterpreting them, I may also use them to explain the growth of fringe benefits. I discuss each in turn.

\subsubsection{The Agency Model}

This model was developed by Lazear $(1979,1981)$ as an extension of that of Becker (1964). The fundamental idea of this model is that the optimal age-earnings strategy for a firm is to pay workers less than their marginal value product in their early years with the firm and more in their later years. There are several reasons for this strategy. First, an employee who has received costly training may quit before the firm has recouped the cost of training or may engage in a suboptimal level of shirking. Lazear emphasized the importance of deferred compensation to increase the employee's 
opportunity cost of quitting or shirking, with its attendant prospects of being discharged. Second, fringe payments may increase workers' productivity directly. Third, and somewhat contrary to the second view, Medoff and Abraham (1980) find that productivity grows far less than is proportionate to earnings with length of service in the firm. If this finding is true, a steeper age-earnings profile would increase a worker's incentive to shirk.

Several reservations may be raised about agency theory. First, the model refers implicitly to total labor compensation rather than to fringe benefits only. Second, the causal mechanism is not entirely clear. Third, some empirical evidence on the difference in working hours between younger workers and older workers contradicts the theory. Fourth, it is not easy to distinguish between human capital theory and agency theory using wage data.

\subsubsection{Tax Advantage Theory}

Tax advantage theory offers three basic arguments. The first is based on the fact that most forms of nonwage compensation are not taxed as income. Standard microeconomic theory leads us to conjecture that employers could reduce compensation costs without reducing employee utility by offering compensation packages that contain untaxed, nonwage employee benefits. This provides employers with an incentive to raise the amount of nonwage compensation.

Second, and somewhat related to the argument of the agency model, Mumy (1985) has shown that deferred payment has a clear advantage when payroll taxes, social security benefits, and income taxes are taken into account. The reason is as follows: When wage income is deferred, the present value of payroll taxes on the income declines. In addition, this wage income later enters the calculation of average earnings for social security payments in an undiscounted manner. In other words, the social security and payroll tax systems provide incentives to defer compensation early in working life, thus avoiding payroll taxes and allowing pension benefits to accrue. The concentration of compensation later in life raises the average earnings base for social security benefits. Again, the same reservations expressed for agency theory are applicable here.

Third, corporate tax laws favor employer contributions to social security and pension funds because of deductibility from employers' taxable income.

In sum, the tax advantage model is quite promising for interpreting the rapid growth of nonwage labor costs and, in particular, pensions. A nice example of the relevance of this theory is provided by the rapid growth in enterprise pension systems, such as $401(\mathrm{k}) \mathrm{s}$, in the United States (e.g., Poterba, Venti, and Wise 1994).

\subsubsection{Worker Preference}

A large number of empirical studies such as Freeman (1981), Lester (1967), and Woodbury (1983) find that unionized firms provide a higher 
proportion of total compensation in the form of fringe benefits than nonunionized firms. One exception is Reynolds (1974). Since the union places a greater weight on the preferences of older workers and permanent workers, who are likely to prefer deferred compensation such as health insurance and pensions over wages, unionized firms tend to have higher proportions of fringe benefits. This argument is an application of the median voter model advocated by Freeman and Medoff (1979). See Tachibanaki and Noda (2000) on Japanese unions that prefer such arrangements. The fact that large Japanese firms have reacted positively to their unions' preferences is interesting.

It must be noted, however, that although the theory of union preference is reasonably persuasive, we have to offer an adequate explanation for why nonunionized firms prefer fringe benefits in some countries and why highly unionized countries, such as Germany and Sweden, have low rates of voluntary, nonwage labor costs.

The case of Germany and Sweden is not complicated. These countries have a higher rate of statutory social welfare programs, and thus the necessity of nonstatutory social programs is greatly reduced. It would be interesting, however, to investigate whether relying more heavily on statutory or nonstatutory social welfare programs is more efficient.

The case of nonunionized firms is not as simple. The tax advantage model may provide an adequate explanation. Both employers and employees may agree to raise the share of deferred payments in order to take advantage of the favorable tax treatment of these payments. It is possible that firms also pay fringe benefits on a purely voluntary basis outside of the system of collective bargaining to secure employees' loyalty.

\subsubsection{Cost Savings apart from Tax Advantages}

A specialized agent, like an insurance company, can offer insurance for a low charge. Each employee's costs are reduced if a large number of workers can form a group insurance program with the consent of an employer. Management costs of pensions and insurance programs can also be reduced if employers and their employees administer, monitor, and evaluate their programs collectively. These cost-saving features encourage employers and their employees to increase the number of fringe benefit programs and concomitant employer expenditures on these programs.

\subsubsection{Better Industrial Relations}

In section 11.3, I noted the relatively high share of nonstatutory fringe benefits in large firms in Japan. One reason for this phenomenon is that larger firms want to have better industrial relations and so pay higher fringe benefits to their employees. Generous treatment, through better housing facilities, health insurance, free lunches, cultural and athletic facilities, and so forth, attracts more qualified workers and reduces turnover. 
Firms can also expect to reap returns from the high motivation and hard work of their employees. In addition, large firms hesitate to pay relatively high wages because harmony in the industry is believed to be important. These are the main reasons why large firms in Japan pay considerably high proportions of compensation in the form of fringe benefits. Trade unions in these firms have responded positively to these benefits. Thus, both employers and employees have been cooperative, as Tachibanaki and Noda (2000) document.

\subsection{Tax Incidence and Policy Issues}

There are at least five important criticisms of high employer contributions to social security and nonstatutory fringe benefits. First, high rates of contribution increase labor costs in general, which is detrimental to the financial condition of a firm and thus to employment. Second, the increase in labor costs may encourage firms to employ more capital-intensive techniques. This is again harmful to employment. Third, and related to the second point, labor-intensive industries are hurt more than capital-intensive industries. Fourth, nonmanual workers (or skilled workers) will be preferred to manual workers (or unskilled workers) due to the wage ceiling used in the determination of the contribution rate. Fifth, since benefits of welfare provision are enjoyed almost entirely by individual persons, it is conceivable to relieve firms of their contributions to welfare provision. The reduction in these contributions could be used to increase employment, wages, or both.

The extremely important subject of payroll tax incidence must also be considered here. It is crucial to understand who actually bears the burden of employer contributions. Three cases are possible: (a) backward shifting, in which a firm passes employer contributions (payroll taxes) on to its employees; (b) forward shifting, in which a firm passes the tax on to consumers in the form of price increases; and (c) no shifting at all. The previous five propositions regarding the effect of the firm contribution rate on employment are made under the presumption that firms do not shift the burden at all. When the direction and the degree of tax shifting are known, these stories may have to be substantially modified. Several theoretical and empirical results on payroll tax incidence follow.

\subsubsection{Payroll Tax Incidence}

In a competitive market, the incidence of a payroll tax depends upon two parameters, the elasticities of labor supply and labor demand. If capital is considered an additional factor input, the substitutability of capital and labor also plays an important role. The common technique for estimating the payroll tax incidence was initiated by Brittain (1972), who estimated a labor demand equation derived from a production function. The effect of a 
payroll tax is then estimated indirectly. This technique is based on a common understanding that payroll taxes are mostly borne by labor in the long run because long-run labor supply is perfectly inelastic (or very inelastic). Break (1974) found this to be mainly true for the United States. In other words, it was believed that employer contributions were fully shifted backward to workers' real wages.

Feldstein (1974) proposes a model of payroll tax incidence that assumes that labor supply is not necessarily inelastic. He also introduces a growth dynamic into the model through capital accumulation. When estimates of labor supply and labor demand elasticities are applied to this model, a slightly different result is obtained. For example, Beach and Balfour (1983) use U.K. data to estimate that only 45 to 60 percent of payroll taxes are shifted back to labor for prime-age males, and 14 to 19 percent for married women. Since the labor supply elasticity of married women is very highsay, 0.8 to 1.1 , as compared to 0.08 to 0.20 for men-only a small portion of their payroll tax is shifted back. Thus, the effect of the payroll tax is equally shared between wage loss and employment reduction for married women, and the major effect is on wages for men. Irish results tell a similar story. Kirwan (1979) adopts a higher value of the elasticity of labor supply, 0.74, while Hughes (1985) uses a lower value, 0.21. The estimated results on shifting turn out to be considerably different. Consequently, a hypothetical reduction in the employer contribution rate produces different estimates of job creation for each elasticity estimate. These two studies clearly show the importance of the labor supply elasticity in estimating the incidence of the payroll tax as well as the number of jobs created or lost due to changes in the rate of employer contributions.

Hamermesh (1979) estimates that 36 percent of the U.S. payroll tax is borne by labor as lower wages (his study is restricted to white males). Although his paper acknowledges the differences in labor supply elasticities among demographic groups, he fails to incorporate such differences. Rather, he emphasizes the adjustment process of labor demand and supply. Extending the idea of the adjustment process, Hamermesh (1980) obtains the result that the impact of a change in the payroll tax rate on wages is delayed for several years because the adjustment of both labor supply and labor demand is not instantaneous. He then applies recently estimated values of the adjustment coefficients to estimate his result.

Another important finding of Hamermesh (1980) is that the response to a decrease in the payroll tax is much slower than the response to an increase. This asymmetry arises from the fact that the adjustment of actual to desired labor supply is slower than that of actual to desired labor demand in the Barro-Grossman (1976) employment model he utilizes. The Barro-Grossman employment model specifies that actual employment must be the minimum of labor supplied and demanded. This asymmetry has an important policy implication: When the tax rate is increased, em- 
ployment adjusts quickly (i.e., employment is cut quickly because labor demand is the binding constraint); when the tax rate is decreased, employment increases only slowly because labor supply is the constraint. Thus, a policy aimed at lowering the payroll tax rate in order to increase employment has only limited value, whereas increasing the tax rate is quite detrimental to employment.

Two reservations are forthcoming at this point. First, it may still be worthwhile to decrease the payroll tax rate in order to increase employment in economies where the observed rate of unemployment is very high, as is the case in several European nations. Second, it is necessary to keep in mind that the supply elasticities for both men and women are considerably higher in countries where the average tax burden (including both income and payroll taxes) is relatively heavy (e.g., Blomquist 1983 on Sweden). In such countries a downward adjustment in employment may be accomplished more quickly than is suggested by the model.

What is the incidence of the payroll tax in an economy in which both factor and product markets are imperfectly competitive? Unions may resist the lowering of real wages in order to maintain real purchasing power. Firms with monopoly power may raise product prices and pass on the tax increases to consumers, that is, forward shifting. Leuthold (1975), among others, tackles this problem for the United States. She concludes that labor contracts and union actions effectively prevent real wages from falling rapidly, but much work is needed to obtain a more conclusive result in this field.

In addition to the common technique described above, several authors have applied another estimation method, a macroeconomic, or Phillipscurve, approach. Perry (1970) proposes that an increase in employer contributions did not lead to any decrease in wages. Gordon (1971), on the contrary, suggests that employer contributions were shifted back to wages entirely. Vroman (1974) shows a result somewhere in between. All of these studies were conducted for the United States, and the results are quite varied. Holmlund (1983) estimates the payroll tax incidence for Sweden using a similar but more sophisticated method. He concludes that only a fraction (roughly 40 percent) of postwar Swedish payroll tax increases were directly shifted back onto labor as lower wage increases. He also finds that around 30 percent of employer contributions in the United States were shifted back.

In sum, studies of payroll tax incidence suggest that only a small portion of employer contributions is shifted back onto labor. The degree depends on many factors and is very sensitive to the elasticity parameters used. However, it must be emphasized that only one study, Perry (1970), has found no backward shifting at all. Some backward shifting almost certainly occurs.

It is somewhat strange that interest in the study of payroll tax incidence has waned in recent years. I suggest the following two reasons for this. 
First, there is a widespread belief that only a small portion of employer contributions is shifted back onto labor. Thus, there is no strong incentive to add a new result. Second, several technical issues have not yet been solved. Thus, unless a new estimation method is invented, a different result cannot be expected.

\subsubsection{Incidence in Japan}

My estimation method is discussed briefly below. There are basically two approaches to estimating payroll tax (i.e., employers' contributions to social security) incidence. The first is a time series estimation method, as utilized by Hammermesh (1980), Beach and Balfour (1983), and Holmlund (1983). The second is a cross-sectional estimation method (i.e., states and occupations), as utilized by Gruber and Krueger (1991). Cross-sectional analyses cannot be easily performed if a national-level social security system applies uniformly to all firms and workers, unlike the American employer-provided health insurance system analyzed by Gruber and Krueger. Since the Japanese social insurance system for employees is fairly universal for all firms and workers, I use a time series estimation method.

The basic method relies on the estimation of the demand for labor, as shown, for example, by Beach and Balfour (1983). The demand for labor under a generalized constant elasticity of substitution (CES) production function is given by equation (1):

$$
Y_{i}=\left[\alpha_{1}\left(e^{\lambda i} L_{i}\right)^{(\sigma-1) / \sigma}+\alpha_{2}\left(e^{\mu i} K_{i}\right)^{(\sigma-1) / \sigma}\right]^{\sigma /(\sigma-1)},
$$

where $Y$ is real output, $L$ is man-hours of labor input, $K$ is capital input, $\sigma$ is the elasticity substitution between capital and labor, $\lambda$ and $\mu$ are factoraugmenting technical change parameters, and $i$ specifies the time period.

We can write the demand for labor by equating the marginal product of labor to the real wage, as follows:

$$
\ln L_{i}=\alpha+\beta_{1} T+\beta_{2} \ln (W / P)_{i}^{*}+\beta_{3} \ln Y_{i}^{*}+u_{i},
$$

where $T$ is a time-trend variable and $*$ implies the optimal level that is calculated using the marginal productivity condition. Gross labor costs are denoted by $(W / P)(1+S t)$ where $W$ is the net wage, $S(0 \leq S \leq 1)$ is the shift parameter, and $t$ is the payroll tax rate. If $S$ is equal to 1 after estimation, there is full backward shifting, implying that the presence of the payroll tax lowers the net wage by the amount of the tax. If $S$ is 0 there is no shifting, implying that the net wage is not affected by the payroll tax. The former signifies full offsets, and the latter signifies no effect. In other words, the former implies that employees bear the entire burden of the payroll tax, whereas the latter implies that employers bear the whole burden.

The demand for labor can thus be estimated by

(3) $\ln L_{1}=\alpha+\beta_{1} T+\beta_{2} \ln (W / P)_{i}^{*}+\beta_{2} S \ln \left(1+t_{i}\right)^{*}+\beta_{3} \ln Y_{i}^{*}+u_{i}$. 
I have to specify the desired level of each variable, namely $\ln (W / P)_{i}^{*}, \ln (1$ $\left.+t_{i}\right)^{*}$, and $\ln Y_{i}^{*}$, because they are not observed. I do this by assuming a rational-expectations framework, in which $(W / P)_{i}^{*}=\ln (W / P)_{i-j}, \ln (1+$ $\left.t_{i}\right)^{*}=\ln \left(1+t_{i-j}\right)$, and $\ln Y_{i}^{*}=\ln Y_{i-j}$, where $j$ denotes a lag. These values can be estimated with the data.

The estimated result of Tachibanaki and Yokoyama (2002) suggests that it is impossible to find any significant shifting except for a few cases of samples divided by sex and industry. It implies that nearly all employers' contributions to social security are borne by employers (i.e., firms). This gives us important policy implications.

\subsection{Recommendations for Japan}

Our empirical result regarding the direction and degree of shifting of employers' contributions to social security in Japan suggests the following policy implications. First, employers bear nearly the entire burden of firms' contributions. Thus, if the society had a consensus such that firms should be free from any contributions to social insurance, the portion paid by firms to social insurance could be used freely for purposes other than firms' contributions to social security.

Second, it is reasonable to expect that nearly all of social security benefits should be financed by employees. This is true in particular when the burden of employers' contributions to social security is too high, damaging the investment and employment activities of firms.

Third, Tachibanaki's (1997b) proposal that firm contributions to social security could be transformed into wage payments must be modified in light of the incidence results. The proposal emphasizes that higher wages enable employees to contribute more to social security, and they also provide greater freedom of consumption. Freedom of consumption implies that the wage increase resulting from decreased employer contributions to social security would be spent freely by employees. Great modifications to this proposal, however, are necessary given the current finding that no major part of firm contributions to social security are shifted to employees in Japan.

There are three choices for such modifications. The first choice is to abandon or reduce firms' contributions to social security if the burden is believed to be too heavy, and thus to expect employees to accept a lower level of social security benefits. Since it is not desirable to lower benefits, someone would have to accept a higher financial burden to compensate for the reduction in social security contributions. I suppose that this group will have to be all citizens. The second choice is that only nonstatutory fringe benefits should be transformed into wage payments. The third is to consider a new financing method for social security if employees are not willing to accept lower social security benefits.

My own preference is for a combination of the above choices, for the fol- 
lowing reasons. First, it is desirable to reduce the burden of firms' contributions to social security in order to allow firms to better concentrate on their business activities. I add the fact that firms' contributions to social security are likely to have a distortionary impact on labor allocations, as was proposed previously.

Second, there is no strong justification for believing that firms should be responsible for the social security benefits of workers. I believe that a firm's responsibility is to engage in prosperous economic activity and thus to keep employment high, with possibly higher wages. Incidentally, selfemployed workers and farmers have no outside support like employer contributions.

Third, it is desirable to have a social security system whose financing is borne by beneficiaries. One way to have such a system is to shift the basis of the financing method from a social insurance principle to a tax principle. Okamoto and Tachnibanaki (2002) performed a simulation study that proposed that the best financing method is to introduce a nonlinear (i.e., progressive) expenditure tax, replacing current social security contributions paid by both employers and employees. "Best" here implies that the impacts on both efficiency and equity were incorporated into the welfare measure.

\subsection{Concluding Remarks}

This paper proposes that firms in Japan can withdraw from welfare provision. The concrete method is as follows: (a) a transformation of nonstatutory fringe benefits to wage payments; (b) a withdrawal of firms' statutory social security contributions; and (c) an introduction of a progressive expenditure tax to compensate for such a withdrawal.

I offer several reasons why both employers and employees have preferred nonwage payments in the past. It is technically necessary to discuss why these reasons are no longer applicable in Japan. However, since Tachibanaki $(1997 \mathrm{a}, \mathrm{b})$ and the previous part of this paper engage in such a discussion, here I only briefly describe several items to supplement the justifications of my proposal.

First, the argument of the agency model is no longer applicable because the basis of wage determination is shifting from the seniority system to the merit system, and thus the age-wage profile is flattening.

Second, tax advantage theory has not been a driving force in Japan, unlike in the United States, where preferential tax treatment encourages American firms and workers to adopt employer-provided health insurance and pension programs (see Tachibanaki 2000a) for the case of Japan).

Third, employers wish to reduce the burden of firm contributions to welfare provision, as shown in appendix A. Also, employees want higher wage payments, rather than nonstatutory fringe benefits (appendix B), since 
there is currently an increasing trend in labor turnover in Japan. The advantages of nonstatutory fringe benefits are greatest when there are few turnovers.

Fourth, the Japanese industrial relations system is changing, and better industrial relations can be achieved without relying on either nonwage payments or nonstatutory fringe benefits. In other words, fair wage payments and promotion systems are more important than generous fringe benefits for sustaining better industrial relations in Japan (see Tachibanaki 1997a and Tachibanaki and Taki 2000 for details).

Finally, trade unions in Japan may be reluctant to accept my proposal because union members are employed in large firms and are therefore the biggest beneficiaries of the current firm-financed system of welfare provision. Two recent phenomena are likely to mitigate this opposition. First, the trade union participation rate is decreasing: It is currently only 22 percent. Second, a large portion of both union and nonunion members now accept the idea that their ultimate goal is to work and to receive fair wage payments and do not expect the welfare provisions that have been offered by firms (see Tachibanaki and Noda 2000).

\section{Appendix A}

\section{Firm Attitudes Toward Welfare Provision}

This appendix presents results based on the Questionnaire on Welfare Provisions survey, prepared by the Cultural Center for Life Insurance in 1998. About 1,400 firms responded. This appendix references only a very small portion of the questions asked in the survey.

One question asks the following: Does your firm increase (a) the share of wages and bonuses, or (b) the share of welfare provision when revenue is distributed? The distribution of each answer was (a), 14.6 percent; somewhat (a), 28.2 percent; indifferent, 32.4 percent; somewhat (b), 18.7 percent; and (b), 6.0 percent. The responses clearly indicate that firms prefer to increase wages (total 42.8 percent) rather than welfare provision (total 24.7 percent).

Another question asks the following: Does (or will) your firm support (a) or (b) regarding the role of welfare provision? Option (a) signifies that firms, rather than employees, are responsible for welfare provision, and (b) signifies that employees, rather than firms, should be responsible. The questionnaire asks for a judgment on current status and future status separately.

The distribution of each answer is as follows: for current status, (a), 7.5 percent; somewhat (a), 22.4 percent; indifferent, 31.1 percent; somewhat 
(b), 27.4 percent; and (b), 11.3 percent. For future status, (a), 6.0 percent; somewhat (a), 16.4 percent; indifferent, 38.9 percent; somewhat (b), 27.4 percent; and (b), 11.0 percent. The responses indicate that the share of (b) is considerably higher than the share of (a) for both current and future judgment, suggesting that firms believe that employees, rather than firms, should be responsible for welfare provision. The shift from the current judgment to the future is minor; there is a small decrease in the "somewhat (a)" category and an increase in the "indifferent" group.

The final question noted here concerns enterprise pension plans. The question asks, is your firm interested in defined contribution pension plans? The distribution of answers is yes, 11.8 percent; no, 87.6 percent; and no answer, 0.5 percent. It is surprising that the vast majority of firms in Japan shows no interest in defined contribution plans, unlike in the United States, where they are very popular. The reasons defined contribution plans are unpopular in Japan are explained in detail in Tachibanaki (2000a).

\section{Appendix B}

\section{Employee Preferences for Welfare Provision}

The 1999 Survey on Life Plan (2000; sample size 1,350) found that the ratio of nonstatutory, nonwage payments to nonstatutory fringe benefit payments was 0.30 , while the ratio of severance payments to enterprise pensions paid was 0.70 . One question asks employees the following: What proportion would be ideal, if you had a chance to choose among (a) nonstatutory fringe benefits, (b) severance payments and enterprise pensions, and (c) wage payment? The answer was (a) 0.16 , (b) 0.38 , and (c) 0.46 , implying that employees would like to receive about 50 percent of nonstatutory, nonwage payments as wages. These figures regarding employee preferences strongly support my proposal that a large portion of nonwage payments should be shifted to wages. Employees are less fond of receiving nonstatutory fringe benefits.

\section{References}

Barro, R. J., and H. J. Grossman. 1976. Money, employment, and inflation. Cambridge: Cambridge University Press.

Beach, C. M. and F. S. Balfour. 1983. Estimated payroll tax incidence and aggregate demand for labour in the U.K. Economica 50:35-48. 
Becker, G. S. 1964. Human capital: A theoretical and empirical analysis with special reference to education. New York: National Bureau of Economic Research.

Blomquist, N. J. 1983. The effect of income taxation on the labour supply of married men in Sweden. Journal of Public Economics 22 (November): 169-97.

Break, G. 1974. The incidence and economic effects of taxation. In The economics of public finance, ed. G. Break, Washington, D.C.: Brookings Institution.

Brittain, J. A. 1972. The payroll tax for Social Security. Washington, D.C.: Brookings Institution.

Cultural Center for Life Insurance. 1998. Questionnaire on welfare provisions. Tokyo: Cultural Center for Life Insurance.

Feldstein, M. S. 1974. Tax incidence with growth and variable factor supply. Quarterly Journal of Economics 87 (November): 551-73.

Freeman, R. B. 1981. The effect of unionization on retirement. Industrial and Labour Relations Review 34 (July): 489-509.

Freeman, R. B., and J. L. Medoff. 1979. The two faces of unionism. The Public Interest 57:69-93.

Freeman, R. B., R. Topel, and B. Swedenborg, eds. 1997. The welfare state in transition. New York: NBER.

Gordon, R. J. 1971. Inflation in recession and recovery. Brookings Papers on Economic Activity, Issue no. 1:105-66.

Gruber, J., and A. B. Krueger. 1991. The incidence of mandated employerprovided insurance: Lessons from workers' compensation insurance. In Tax policy and the economy, ed. D. Bradford, 110-43. Cambridge: MIT Press.

Hamermesh, D. 1979. New estimates of the incidence of the payroll tax. Southern Economic Journal 45 (April): 1208-19.

. 1980. Factor market dynamics and the incidence of taxes and subsidies. Quarterly Journal of Economics 95 (December): 751-64.

Hart, R. A. 1984. The economics of non-wage labour costs. London: Allen and Unwin.

Holmlund, B. 1983. Payroll taxes and wage inflation: The Swedish experience. Scandinavian Journal of Economics 85 (1): 1-15.

Hughes, G. 1985. Payroll tax incidence, the direct tax burden, and the rate of return of state pension contributions in Ireland. Dublin: Economic and Social Research Institute.

Katsumata, Y. 2000. International comparison of data construction in international comparison (in Japanese). Kaigai Shakai-Hosho Kenkyu 130 (Spring): $25-46$.

Katsumata, Y., and Y. Morita. 1999. Fundamental data on social security costs: International comparisons and interpretations (in Japanese). Kaigai Shakai-Hosho Kenkyu 128 (Autumn): 104-16.

Kirwan, F. X. 1979. Non-wage costs, employment, and hours of work in Irish manufacturing industry. Economic and Social Review 10:231-54.

Lazear, E. P. 1979. Why is there mandatory retirement? Journal of Political Economy 87 (December): 1261-68.

- 1981. Agency, earnings profiles, productivity, and hours restrictions. American Economic Review 71 (September): 606-20.

Lester, R. A. 1967. Benefits as a preferred form of compensation. Southern Economic Journal 33 (April): 485-95.

Leuthold, J. H. 1975. The incidence of the payroll tax in the United States. Public Finance Quarterly 1 (January): 3-13.

Medoff, J. L., and K. G. Abraham. 1980. Experience, performance, and earnings. Quarterly Journal of Economics 95:703-36. 
Ministry of Labor. 1997. 1996 General survey on wages and working hours system. Tokyo: Ministry of Labor.

Mumy, G. E. 1985. The role of taxes and social security in determining the structure of wages and pensions. Journal of Political Economy 93 (3): 574-85.

Okamoto, A., and T. Tachibanaki. 2002. Integration of tax and social security system: On the financing methods of public pension scheme in pay-as-you-go system. In Social security reform in advanced countries, ed. T. Ihori and T. Tachibanaki. London: Routledge.

Organization for Economic Co-operation and Development (OECD). 1997. The tax/benefit position of employees 1995-1996. Paris: Organization for Economic Co-operation and Development.

- 1998. Public management reform and economic and social development. Paris: Organization for Economic Co-operation and Development.

Perry, G. 1970. Changing labour market and inflation. Brookings Papers on Economic Activity, Issue no. 3:411-41.

Poterba, J. M., S. F. Venti, and D. A. Wise. 1994. 401(k) plans and tax-deferred saving. In Studies in the economics of aging, ed. D. Wise, 105-38. Chicago: University of Chicago Press.

Rein, M. 1996. Is America exceptional? The Role of occupational welfare in the United States and the European Community. In The privatization of social policy? Occupational welfare and the welfare state in America, Scandinavia, and Japan, ed. M. Shalev, London: Macmillan.

Reynolds, L. G. 1974. Labor economics and labor relations. Englewood Cliffs, N.J.: Prentice-Hall.

Rice, R. 1966. Skill, earnings, and growth of wage-supplements. American Economic Review 54 (2): 583-93.

Survey on life 1999. 2000. Osaka: Kansai Economic Research Center.

Tachibanaki, T. 1996. Wage determination and distribution in Japan. Oxford, U.K.: Clarendon.

-1997a. Labor policies and welfare programs. In Long-run perspective of the Japanese economy for the 21st century (in Japanese), ed. R. Komiya and M. Okuno, 219-38. Tokyo: Toyokeizai Shimposha.

. 1997b. Labor policies in firms: Wage payments or non-wage payments? In Support for life in an aging society (in Japanese), ed. N. Yashiro, 99-116. Tokyo: University of Tokyo Press. bun-sha. . 2000a. Economics of the safety net (in Japanese). Tokyo: Nihon Keizai Shi2000b. Japan was not a welfare state, but. In From austerity to affluence, ed. R. Griffits and T. Tachibanaki, 188-208. London: Macmillan.

Tachibanaki, T., and T. Noda. 2000. The economic effects of trade unions in Japan. London: Macmillan.

Tachibanaki, T., and A. Taki. 2000. Capital and labour in Japan: The function of two factor markets. London: Routledge.

Tachibanaki, T., and Y. Yokoyama. 2002. The estimation of the incidence of employer contributions to social security. Kyoto University and Kobe University of Commerce. Mimeograph.

Vroman, W. 1974. Employer payroll taxes and money wage behaviour. Applied Economics 6:189-204.

Woodbury, S. A. 1983. Substitution between wage and non-wage benefits. American Economic Review 73 (March): 166-82. 
